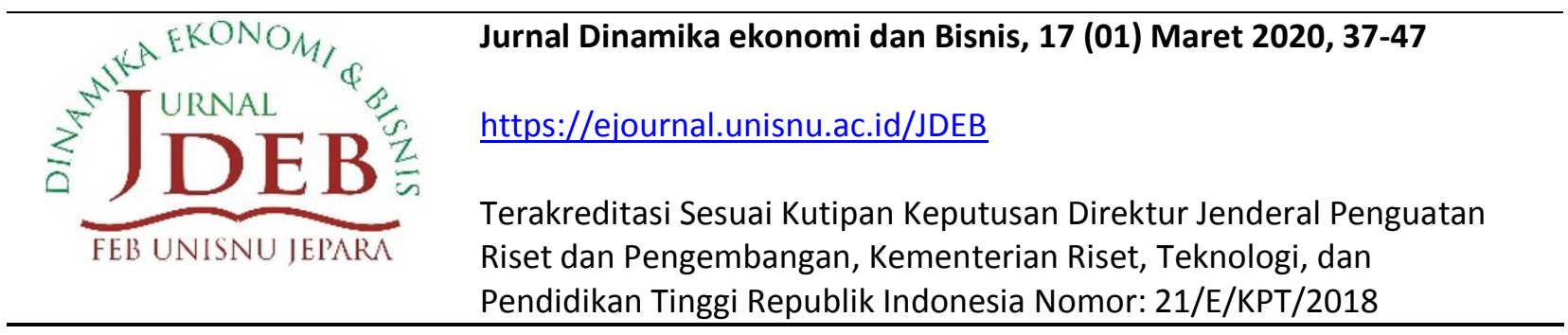

\title{
SINERGITAS PERBANKAN DAN FINANCIAL TECHNOLOGY: IKHTIAR MENUJU INKLUSIVITAS KEUANGAN MASYARAKAT UNBANKABLE
}

\author{
Abdul Aziz $^{1) *}$, Dini Maulana Lestari ${ }^{2)}$, Reni Furwanti ${ }^{3)}$ \\ Faculty of Business and Islamic Economy, State Islamic University of Sunan Kalijaga Yogyakarta ${ }^{1,2,3)}$ \\ Email: aziz248@gmail.com ${ }^{1)}$,maulanalestari87@gmail.com ${ }^{2)}$, renifurwanti96@gmail.com ${ }^{3)}$
}

\begin{abstract}
Financial technology era is forced such financial institutions become digitalize in today's world regarding to increasing financial inclusion and empowering unbanked societies. Nevertheless, this phenomenon is not override the function of bank which is the earlier financial institution that is splashing around in the term of financial inclusion. Actually, those two financial institutions have such strengthen and weakness in order to operate their primary activities in the term of funding and financing, thus, if banking and financial institutions are collaborating it could be fulfilled their main function each other regarding to rising up such financial inclusion of unbanked society. This research discusses the cooperation between banking and financial technology institutions in order to increase financial inclusion of unbanked society. Also, this is kind of qualitative descriptive research through the philosophy of positivism approach. As the result, this research delineates if bank and financial technology institutions are collaborating it could increase the rate of financial inclusion of unbanked citizens effectively and efficiently, not only that, but it would worth for those two institutions in the term of operational.
\end{abstract}

Keywords: Financial Inclusion, Financial technology, Unbankable Society, Banking, Cooperation.

\begin{abstract}
Abstrak
Digitalisasi lembaga keuangan di era fintech mengalami perkembangan cukup pesat dewasa kini, guna untuk meningkatkan inklusifitas keuangan serta memberdayakan masyarakat unbanked. Kendati demikian, hal tersebut tidak serta merta mengesampingkan kontribusi lembaga perbankan yang lebih dahulu berkecimpung dalam peran keuangan inklusif. Kedua lembaga jasa keuangan tersebut sejatinya memiliki kekuatan dan kelemahan dalam menjalankan fungsinya, sehingga apabila kedua lembaga tersebut saling bersinergi, maka dapat saling melengkapi peran dari masing-masing lembaga keuangan tersebut dalam meningkatkan inklusi keuangan masyarakat unbankable. Penelitian ini akan membahas mengenai sinergitas perbankan dan lembaga financial technology dalam rangka meningkatkan inklusi keuangan masyarakat unbanked. Penelitian ini menggunakan pendekatan deskriptif kualitatif eksploratif dengan pendekatan filsafat positivism, atau paradigma interpretatif dan konstruktif yang memandang realitas social dengan sesuatu yang holistic atau utuh, kompleks, dinamis serta penuh makna dengan hubungan gejala bersifat interaktif. Hasil dari penelitian ini menjelaskan bahwa apabila perbankan dan lembaga fintech berkolaborasi, di samping dapat meningkatkan inklusifitas masyarakat unbanked secara efektif dan efisien, hal ini juga dapat menguntungkan kedua pihak lembaga jasa keuangan tersebut dalam segi operasionalnya.
\end{abstract}

Kata Kunci: Inklusi Keuangan, Lembaga Fintech, Masyarakat Unbankable, Perbankan, Sinergitas.

Sitasi: Azis, A., Lestari, D. M., dan Furwanti, R. (2020). Sinergitas Perbankan dan Financial Technology: Ikhtiar Menuju Inklusivitas Keuangan Masyarakat Unbankable. Jurnal Dinamika Ekonomi dan Bisnis, 17 (01) 2020, 37-47. 


\section{PENDAHULUAN}

Keberadaan sektor perbankan menjadi satu bagian penting dari lembaga keuangan formal di Indonesia karena sangat mampu untuk mengimplementasikan financial inclusion (Sadari dan Hakim, 2019). Data survei inklusi keuangan OJK tahun 2016 menyatakan inklusi tertinggi didapatkan oleh perbankan sebesar $63,3 \%$, peransuransian $12,1 \%$, dana pensiun $4,7 \%$, lembaga pembiayaan $11,8 \%$, pergadaian $10,5 \%$, pasar modal $1,3 \%$ (OJK, 2016). Hal ini sesuai dengan akselerasi pertumbuhan kredit perbankan sebesar 11,55\% (yoy) pada Maret 2019, berdasarkan laporan statistik Otoritas Jasa Keuangan (OJK) mengenai perbankan umum di Indonesia sebagai berikut (OJK, 2019a).

Tabel 1. Indikator Bank Umum Konvensional

\begin{tabular}{llllllll}
\hline \multirow{2}{*}{ Indikator } & \multicolumn{3}{c}{ Nominal } & \multicolumn{2}{c}{ qtq } & \multicolumn{2}{c}{ yoy } \\
\cline { 2 - 8 } & Mar'18 & Des'18 & Mar'19 & Des'18 & Mar'19 & Des'18 & Mar'19 \\
\hline $\begin{array}{l}\text { Total Aset } \\
\text { (Rp Milyar) }\end{array}$ & 7.135 .601 & 7.751 .655 & 7.812 .547 & $3.87 \%$ & $0.79 \%$ & $8.58 \%$ & $9.48 \%$ \\
$\begin{array}{l}\text { Kredit (Rp } \\
\text { Milyar) }\end{array}$ & 4.553 .173 & 5.092 .584 & 5.085 .310 & $3.47 \%$ & $-0.14 \%$ & $8.62 \%$ & $11.69 \%$ \\
$\begin{array}{l}\text { Sumber: Otoritas Jasa Keuangan (2019). } \\
\end{array}$ & & & & & \\
\hline
\end{tabular}

Data di atas menunjukkan bahwa persentase kredit perbankan tiap tahunnya mengalami kenaikan secara signifikan. Kendati demikian, keberadaan industri perbankan di Indonesia saat ini dinilai masih terbatas dalam menghimpun dan menyalurkan pendanaan kepada masyarakat. Hal ini diindikasikan banyak masyarakat yang belum bisa mengakses layanan jasa keuangan yang diberikan oleh perbankan dikarenakan proses dan portofolio yang dinilai rumit. Banyaknya masyarakat belum memenuhi syarat-syarat wajib pembiayaan yang telah ditetapkan oleh perbankan menjadi salah satu faktor belum optimalnya inklusi keuangan di Indonesia.

Deputi Direktur Pengaturan, Penelitian, dan Pengembangan Fintech Otoritas Jasa Keuangan (OJK) Munawar Kasan sebagaimana di lansir pada laman harian Kompas.com (2019) menilai bahwa keterbatasan akses atas layanan jasa keuangan yang diberikan perbankan selama ini menjadi salah satu kelemahan atas lembaga keuangan tradisional tersebut. Lebih lanjut dirinya menyatakan bahwa berdasarkan riset yang dilakukan oleh pihak Otoritas Jasa Keuangan (OJK) pada tahun 2016 menyatakan bahwa masih tingginya jarak pendanaan di Indonesia, yakni sekitar Rp. 988 triliun per tahun nya. Hal tersebut dapat diketahui bahwa kebutuhan akan pendanaan per tahunnya sekitar Rp. 1.649 triliun dan hanya mampu dipenuhi oleh lembaga keuangan perbankan sekitar Rp. 660 triliun (Lingga, 2019).

Berkaitan dengan hal tersebut, pada tahun 2010 Bank Indonesia telah meluncurkan National Strategy for Financial Inclusion (NSFI) sebagai salah satu upaya untuk memperluas akses masyarakat terhadap layanan jasa keuangan yang membutuhkan akses lembaga keuangan (unbanked). Namun demikian, hingga saat ini tingkat inklusi keuangan Indonesia belum dapat terpenuhi sepenuhnya sesuai dengan apa yang telah ditargetkan. Hal ini mengindikasikan bahwa masih rendahnya tingkat literasi masyarakat terhadap layanan jasa keuangan industri perbankan yang secara tidak langsung hal tersebut dapat memengaruhi tingkat inklusifitas keuangan masyarakat tersebut (Sadari dan Hakim, 2019). 
Untuk mengatasi hal tersebut, Munawar Kasan mengungkapkan bahwa salah satu solusi untuk mengatasi hal tersebut ialah dengan mengembangkan fintech dengan harapan meningkatkan inklusi keuangan atas masyarakat unbankable. Hal ini sejalan dengan apa yang dilakukan oleh Otoritas Jasa Keuangan yang dewasa kini tengah mengembangkan sistem teknologi finansial, di mana kebijakan tersebut didukung oleh Kementerian Keuangan dan Bank Indonesia yang siap untuk merancang seperangkat aturan mengenai sistem financial technology tersebut.

Financial Technology (fintech) merupakan suatu inovasi terbaru di era modern saat ini. Hadirnya fintech di tengah-tengah masyarakat memiliki peran yang cukup signifikan dalam membantu perkembangan perekonomian. Dalam hal ini dikhususkan mengenai layanan jasa keuangan dalam meningkatkan inklusi keuangan Indonesia. Fintech berpotensi menguntungkan berbagai pihak, mulai dari pelaku bisnis sampai dengan masyarakat yang memanfaatkan layanan tersebut. Berdasarkan hal ini, fintech memiliki peran yang cukup strategis yang tidak dapat dijangkau oleh lembaga jasa keuangan tradisional dalam memberikan pelayanannya secara lebih efektif, efisien dan ekonomis. Pada Juli 2019 perusahaan fintech di Indonesia sudah berjumlah 127 perusahaan fintech dengan klasifikasi 119 fintech konvensional dan 8 fintech syariah. Pertumbuhan kredit berbasis fintech sangat pesat, pada Agustus 2019 tumbuh sebesar 218,5\% (yoy) (OJK, 2019a).

Dalam rangka meningkatkan inklusi keuangan yang diinginkan oleh pemerintah serta memberikan dana kepada masyarakat unbankable, pemerintah bisa memberikan instruksi atau peraturan kepada jasa keuangan untuk melakukan kolaborasi antara jasa keuangan terutama perbankan dan lembaga financial technology sehingga keinginan meningkatkan inklusi ke taraf yang lebih tinggi bisa dicapai. Dengan demikian, hal ini menjadi sebuah kesempatan besar bagi kedua industri jasa keuangan tersebut melalui suatu bentuk kerja sama antara bank dan fintech dalam rangka menyalurkan dana yang belum tersalurkan tersebut, sehingga akan berdampak pada meningkatnya inklusi keuangan secara masif efektif dan efisien. Mengingat pada tahun 2015 Financial Technology (Fintech) mulai menjadi suatu instrumen jasa keuangan yang cukup populer dengan menawarkan sebuah inovasi dari teknologi yang bisa memunculkan sebuah model bisnis baru, aplikasi atau hal yang terkait dengan jasa keuangan (BINUS). Berdasarkan uraian di atas, penelitian ini akan meneliti tentang sinergitas Lembaga perbankan dan fintech sebagai solusi meningkatkan inklusi keuangan masyarakat unbankable. Tujuan yang hendak dicapai dalam penelitian ini adalah memberikan rekomendasi aplikatif kepada lembaga jasa keuangan terkhusus pada sektor perbankan dan sektor fintech dalam mendorong inklusi keuangan masyarakat unbankable.

Penelitian ini akan membahas mengenai sinergitas perbankan dan financial technology dalam mencapai peningkatan inklusifitas keuangan masyarakat unbankable. Perbankan adalah segala sesuatu yang menyangkut tentang bank, mencakup kelembagaan, kegiatan usaha, serta cara dan proses dalam melaksanakan kegiatan. Kasmir (2016) mengemukakan bahwa bank adalah lembaga keuangan yang kegiatan usahanya adalah menghimpun dana dari masyarakat dan menyalurkan kembali dana tersebut ke masyarakat serta memberikan jasa-jasa bank lainnya. Sedangkan fintech menurut The National Digital Research (NDTR) ialah suatu terobosan jasa finansial dari lembaga jasa keuangan berbasis teknologi. Sementara itu, pengertian fintech menurut fintech weekly melalui website nya memaparkan bahwa fintech 
merupakan sebuah bisnis yang bertujuan menyediakan layanan jasa keuangan dengan memanfaatkan software dan teknologi modern sebagai alat utamanya.

Kolaborasi kedua lembaga tersebut dianggap sangat strategis untuk mencapai tujuan dalam meningkatkan inklusi keuangan masyarakat unbankable tanpa merugikan salah satu pihak. Meskipun penelitian ini telah diteliti oleh beberapa peneliti terdahulu, namun ada beberapa perbedaan signifikan antara penelitian ini dengan penelitian-penelitian yang pernah ada sebelumnya.

Sadari dan Hakim (2019) dalam penelitiannya yang berjudul Revitalisasi Keuangan Inklusif dalam Sistem Perbankan Syariah di Era Financial Technology lebih memfokuskan pada pemaksimalan pendayagunaan fintech dalam dunia jasa layanan keuangan guna untuk meningkatkan inklusi keuangan masyarakat. Kehadiran sejumlah perusahaan fintech turut berkontribusi dalam pengembangan perbankan syariah dalam pelayanan yang mudah dan murah serta efektif dan efisien. Tidak hanya sebatas membantu pembiayaan modal usaha, peran fintech juga sudah merambah ke berbagai aspek seperti layanan pembayaran digital dan pengaturan keuangan.

Basuki dan Husein (2018) dalam penelitiannya yang berjudul Analisis SWOT Financial technology pada Dunia Perbankan di Kota Ambon (Survei pada Bank di Kota Ambon) menitikberatkan penelitiannya pada penggalian potensi Fintech guna untuk meningkatkan Inklusi Keuangan masyarakat yang belum tersentuh industri perbankan. Financial Technology yang diimplementasikan memberikan kekuatan, kelemahan, ancaman, peluang bagi dunia perbankan secara bersamaan, sehingga membuat para bankers harus memperbaiki infrastruktur teknologi informasi agar dapat berkolaborasi dengan fintech. Pada gilirannya akan membuat peningkatan layanan dunia perbankan sehingga costumer semakin mendapatkan pengalaman terkini terkait layanan perbankan digital.

Ansori (2019) dalam penelitiannya yang berjudul Perkembangan dan Dampak Financial Technology memfokuskan penelitiannya pada pengaruh fintech terhadap industri keuangan syariah di Jawa Tengah. Di mana hasil yang diperoleh yaitu Fintech memiliki potensi cukup signifikan bersaing dengan lembaga keuangan syariah karena memiliki fiturfitur teknologi mutakhir yang dapat memudahkan masyarakat dalam mengakses layanan jasa keuangan yang belum bisa dijangkau oleh lembaga keuangan tradisional. Sehingga dengan adanya hal tersebut lembaga keuangan Syariah perlu adanya inovasi produk dengan sistem teknologi agar bisa mengimbangi perkembangan zaman dan bekerja sama dengan fintech lending, agar mampu bersaing dengan fintech.

Musdalifah, et al., (2018) dalam penelitiannya yang berjudul Peran Fintech dalam Meningkatkan Keuangan Inklusif Pada UMKM di Indonesia (Pendekatan Keuangan Syariah) lebih memfokuskan pada analisis peran fintech dalam meningkatkan keuangan inklusif pada sektor UMKM. Di mana hasil yang diperoleh yaitu fintech dinilai sangat berpotensi dalam meningkatkan inklusifitas keuangan sektor UMKM. Tidak hanya sebatas membantu dalam hal pembiayaan modal usaha saja, akan tetapi peran fintech juga sudah merambah ke berbagai aspek seperti layanan pembayaran digital, dan pengaturan keuangan.

Berdasarkan beberapa penelitian di atas, dapat ditarik sebuah benang merah yakni baik industri perbankan maupun fintech masing-masing memiliki kelebihan dan kekurangan dalam berkontribusi untuk meningkatkan inklusi keuangan masyarakat unbankable. Namun 
demikian, dari penelitian-penelitian tersebut belum ada yang membahas mengenai keuntungan yang diperoleh apabila lembaga perbankan dan lembaga fintech melakukan kolaborasi atau kerja sama, dalam arti antara lembaga jasa perbankan dan finansial teknologi saling berkolaborasi untuk menghasilkan sebuah inovasi atau terobosan baru yang diindikasikan dapat meningkatkan inklusi keuangan secara lebih efektif dan efisien.

Berdasarkan uraian di atas, penelitian ini menawarkan suatu konsep baru yakni instrumen kolaborasi perbankan dan financial technology dalam mendorong inklusi keuangan masyarakat unbankable. Dengan menggabungkan kedua potensi yang dimiliki oleh kedua lembaga tersebut, diharapkan dapat mengurangi persentase masyarakat unbankable, sehingga tingkat inklusifitas keuangan di Indonesia dapat meningkat secara efektif dan sesuai dengan apa yang telah di targetkan oleh Otoritas Jasa Keuangan (OJK) Indonesia.

\section{METODE}

Berdasarkan uraian yang telah dikemukakan sebelumnya, maka pada bagian ini diuraikan kerangka pemikiran yang dijadikan landasan berpikir dalam melaksanakan penelitian. Pada dasarnya kerangka berpikir yang telah disusun pada penelitian ini akan menjelaskan secara teoritis tujuan yang hendak dicapai dari adanya upaya sinergitas antara lembaga perbankan dan lembaga financial technology. Adapun kerangka berpikir yang dijadikan landasan dalam penelitian ini dapat dilihat pada gambar di bawah ini:

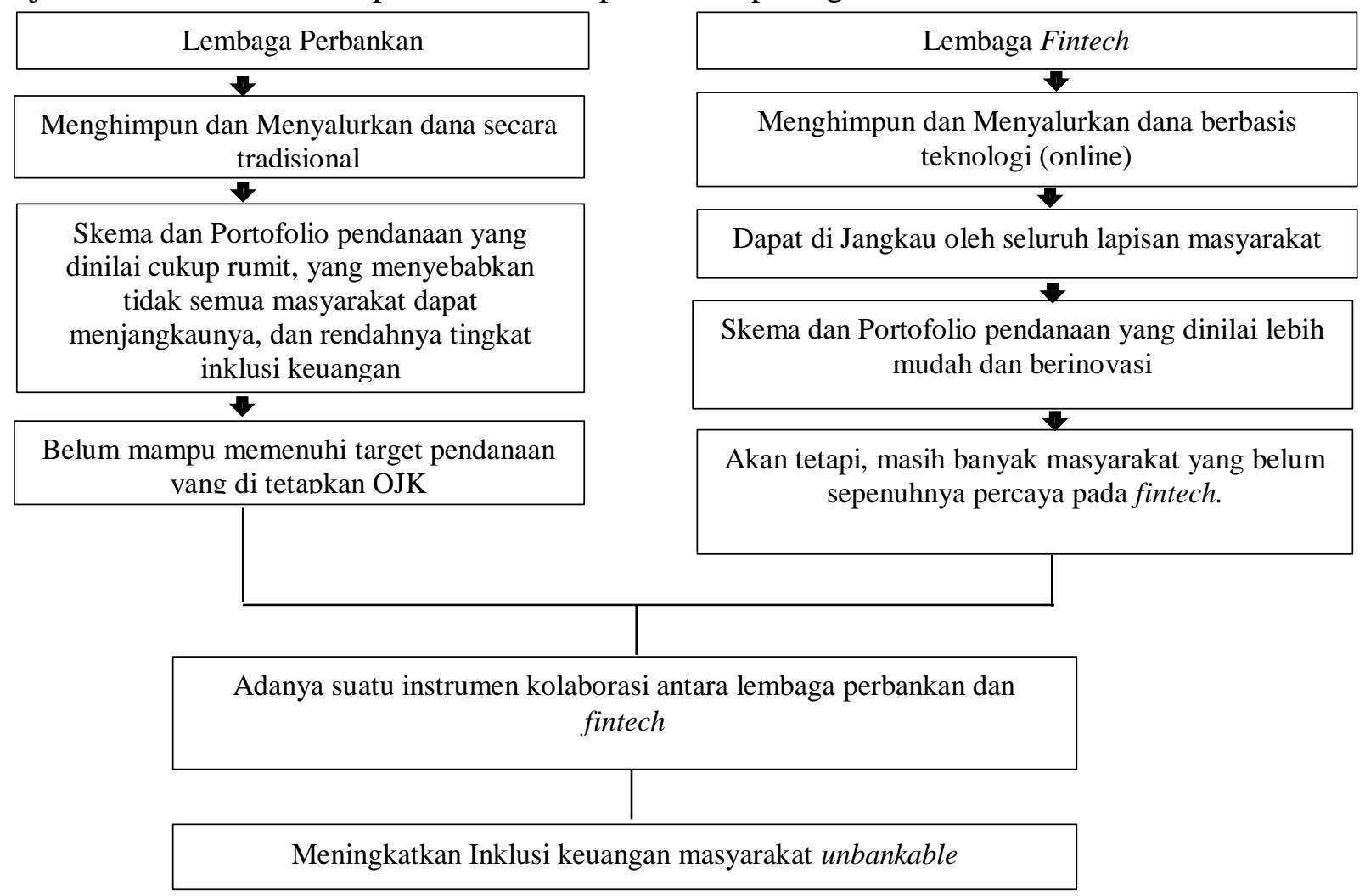

Gambar 1. Kerangka Pemikiran Penelitian 
Pada penelitian ini bersifat deskriptif kualitatif eksploratif dengan pendekatan filsafat positivism, atau paradigma interpretatif dan konstruktif yang memandang realitas sosial dengan sesuatu yang holistic atau utuh, kompleks, dinamis serta penuh makna dengan hubungan gejala bersifat interaktif.

Teknik Pengumpulan data yang digunakan adalah:

a. Dokumentasi

Dokumentasi adalah suatu catatan yang berisi peristiwa masa lalu, dokumen yang bisa berisi tulisan, gambar atau hasil karya monumental dari seseorang (Sugiyono, 2016).

b. Observasi

Menurut Nasution dalam Sugiyono mengatakan bahwa observasi adalah dasar pengetahuan, para peneliti/ilmuwan dapat bekerja bila mendapatkan data fakta dari observasi yang mereka lakukan (Sugiyono, 2016). Observasi dilakukan untuk mendapatkan informasi yang diperlukan guna untuk menjawab pertanyaan penelitian

Analisis data yang dilakukan pada penelitian adalah:

a. Reduksi Data

Merupakan suatu proses penilaian, pemusatan, penyederhanaan, pengabstrakan, dan transformasi data yang muncul dari catatan tertulis di lapangan. Teknik analisis ini diperlukan agar mengarahkan dan menajamkan analisis dengan menggolongkannya dan membuang yang tidak diperlukan.

b. Penyajian Data

Adapun informasi yang tersusun dan memberikan kemungkinan tentang adanya penarikan kesimpulan dan mengambil tindakan. Bentuknya dapat diikuti gambaran atau skema dari beberapa tabel yang di rancang untuk menyusun agar dapat di mengerti. Teknik analisis ini diperlukan oleh peneliti untuk memudahkan peneliti dalam melihat gambaran secara umum tentang apa yang sedang terjadi atau hasil data yang diperoleh selama penelitian sehingga dapat ditentukan apa yang selanjutnya harus dilakukan oleh peneliti.

c. Menarik Kesimpulan

Data yang telah dikumpulkan dan di analisis tersebut dapat ditarik kesimpulankesimpulan. Penarikan kesimpulan dilakukan selama penelitian berlangsung. Teknik analisis data dengan menarik kesimpulan ini peneliti akan memberikan kesimpulan dari hasil analisis data yang telah dilakukan serta memberikan saran-saran sebagai rekomendasi lanjutan untuk kebijakan-kebijakan mengenai peran koperasi wanita dalam membangun keuangan inklusif.

\section{HASIL DAN PEMBAHASAN}

\section{Perbankan dan Lembaga Financial Technology Perkuat Industri Keuangan}

Banyak masyarakat yang ada di daerah atau di pedesaan belum tersentuh oleh layanan perbankan, kebanyakan dari mereka lebih memilih untuk meminjam uang atau kredit menggunakan jasa rentenir untuk mengembangkan usaha atau modal usaha mereka. Menurut survei literasi dan inklusi keuangan OJK tahun 2016 menyatakan bahwa persentase inklusi keuangan Indonesia sebesar $67,8 \%$. Berdasarkan hal ini, terdapat sekitar 32,2\% tingkat inklusi yang belum tersentuh oleh jasa keuangan perbankan, rata-rata masyarakat yang belum tersentuh inklusi tersebut adalah masyarakat unbankable dan berdomisili di daerah pedesaan. 
Menurut CEO PT Investree Radhika Jaya mengungkapkan bahwa ada dana kredit senilai Rp. 800 triliun yang belum terjamah oleh lembaga jasa keuangan tradisional seperti perbankan. Otoritas Jasa Keuangan (OJK) mengemukakan tercatat sebanyak 1000 kantor cabang perbankan yang ditutup selama tiga tahun belakangan. Hal ini mengindikasikan bahwa kurangnya jangkauan perbankan dalam menyalurkan kredit kepada seluruh lapisan masyarakat, disamping itu sulitnya skema dan persyaratan yang harus dipenuhi oleh masyarakat terkait prosedur pengajuan kredit (Wiratno, 2017).

Fintech merupakan salah satu hasil inovasi dari perkembangan teknologi di bidang keuangan yang cukup pesat dewasa kini, mengacu pada pengaplikasian teknologi modern (Chrismastianto, 2017). Ansori (2019) dalam penelitiannya mengungkapkan bahwa adanya inovasi teknologi keuangan ditengah-tengah masyarakat dapat membuat masyarakat lebih mudah dalam menjangkau layanan jasa keuangan secara lebih efektif, efisien, dan ekonomis.

Hal ini juga membuat akses serta kondisi wilayah geografis menjadi suatu target perbankan agar lebih dekat kepada masyarakat, dan tidak menegaskan bahwa layanan jasa keuangan hanya menjadi milik sekelompok masyarakat di perkotaan saja. Dalam arti, adanya masyarakat unbankable di suatu daerah disebabkan karena sulitnya akses lembaga jasa keuangan, monopoli bank pada sektor-sektor tertentu dan terbatasnya saluran distribusi keuangan (Nasution, 2017). Berdasarkan hal ini, diharapkan seluruh lapisan masyarakat dapat menikmati layanan jasa keuangan tanpa terkecuali, dan otomatis ini dapat meningkatkan tingkat inklusi keuangan di suatu daerah bahkan negara.

Hal senada diungkapkan oleh Basuki dan Husein (2018) menyebutkan dalam penelitiannya bahwa peluang fintech dewasa kini semakin berkembang, karena kemudahan yang ditawarkan olehnya. Dengan adanya hal tersebut, dapat meningkatkan industri keuangan inklusif, dan dapat membantu masyarakat unbankable. Kehadiran fintech akan menyebabkan perbankan melakukan digitalisasi dan otomatisasi agar dapat mempermudah pelayanan yang lebih praktis. Masyarakat juga membutuhkan layanan perbankan yang lebih modern. Hal ini mendorong perbankan untuk lebih mengutamakan layanan berbasis teknologi. Oleh karena itu, perbankan dapat berkolaborasi dengan lembaga fintech agar mempermudah dalam memberikan layanan jasa keuangan kepada seluruh lapisan masyarakat.

Industri financial technology merupakan salah satu institusi layanan jasa keuangan yang sedang hype di era digital saat ini. Metode transaksi dan pembayaran secara digital menjadi salah satu sektor dalam industri fintech yang paling berkembang di Indonesia. Sektor inilah yang kemudian paling diharapkan oleh pemerintah dan masyarakat untuk mendorong peningkatan jumlah masyarakat yang memiliki akses kepada layanan keuangan (Sadari, dan Hakim, 2019).

Beberapa layanan produk jasa keuangan fintech seperti crowd funding, mobile payment, peer-to-peer lending, serta PayPay menyebabkan terjadinya revolusi dalam bisnis startup layanan jasa keuangan. Dengan memanfaatkan layanan-layanan jasa keuangan fintech, dapat memberikan peluang yang cukup signifikan pada masyarakat dalam memperoleh dana, dalam arti masyarakat dapat memperoleh sejumlah dana dari seluruh dunia dengan mudah, bahkan dari orang yang belum pernah dikenal atau ditemui sekalipun. Hal ini terjadi karena fintech memiliki wadah yang dianggap proper untuk mengatasi dan memfasilitasi aktivitas tersebut (Ansori, 2019). 
Secara global, industri fintech terus berkembang dengan pesat. Hal ini ditandai dengan maraknya perusahaan-perusahaan start up pada sektor tersebut, dikarenakan besarnya dana investasi global di dalamnya yang mendukung pesatnya perkembangan industri fintech. Dengan kekuatan dan kelebihan yang dimiliki oleh fintech hal tersebut dapat memberikan peran yang cukup fital dalam financial Inclusion (keuangan inklusif) yang dirumuskan untuk mewujudkan sistem keuangan yang dapat diakses oleh seluruh lapisan masyarakat untuk mendorong pertumbuhan ekonomi, penanggulangan kemiskinan, pemerataan pendapatan, dan terciptanya stabilitas sistem keuangan di Indonesia.

Adapun tujuan dari financial inclusion (keuangan inklusif) tersebut dijabarkan dalam beberapa tujuan sebagai berikut (Sadari dan Hakim, 2019):

a. Menjadikan strategi keuangan inklusif sebagai bagian dari strategi besar pembangunan ekonomi, penanggulangan kemiskinan, pemerataan pendapatan dan stabilitas sistem keuangan.

b. Menyediakan jasa dan produk keuangan yang sesuai dengan kebutuhan masyarakat.

c. Meningkatkan pengetahuan masyarakat mengenai layanan keuangan.

d. Meningkatkan akses masyarakat terhadap layanan jasa keuangan.

e. Memperkuat sinergitas antara bank, lembaga keuangan mikro, dan lembaga keuangan nonbank.

f. Mengoptimalkan peran teknologi informasi dan komunikasi (TIK) untuk memperluas cakupan layanan keuangan.

Menurut Otoritas Jasa Keuangan (2017), kelebihan dari fintech ialah sebagai berikut:

a. Dapat melayani masyarakat Indonesia yang belum dapat dilayani oleh industri jasa keuangan tradisional dikarenakan ketatnya peraturan perbankan serta keterbatasan lembaga jasa keuangan tersebut dalam melayani masyarakat di daerah tertentu.

b. Menjadi alternatif pendanaan yang lebih efektif dan efisien serta transparan atas jasa industri keuangan tradisional.

Terlepas dari keunggulan tersebut, fintech juga memiliki beberapa kendala, seperti: (1) Banyaknya lembaga fintech ilegal (tidak terdaftar di Otoritas Jasa Keuangan) yang dapat menimbulkan wanprestasi terhadap nasabah. Hal ini sesuai dengan data yang dikemukakan Otoritas Jasa Keuangan bahwa hanya 113 lembaga fintech yang terdaftar di kantor Otoritas Jasa Keuangan per 31 Mei 2019, ini menandakan bahwa masih sedikitnya jumlah fintech legal (OJK, 2019b). Hal ini memicu rendahnya tingkat kepercayaan masyarakat terhadap lembaga fintech sebagai salah satu lembaga jasa keuangan berbasis online; (2) Masih banyak masyarakat yang belum cakap teknologi dan masih banyak daerah yang belum terkoneksi dengan jaringan internet.

Pada dasarnya perbankan dan lembaga fintech memiliki keunggulan dan kelemahan masing-masing dalam menghimpun dan menyalurkan pendanaan yang dapat mendorong tingkat inklusi keuangan Indonesia. Berdasarkan hal tersebut, akan sangatlah cocok apabila kedua lembaga tersebut melakukan kolaborasi dengan tujuan meningkatkan inklusi keuangan Indonesia sesuai target yang ditetapkan oleh Otoritas Jasa Keuangan.

\section{Sinergitas Perbankan dan Lembaga Financial Technology}

Bank memiliki tupoksi yang cukup besar dalam mengelola dana masyarakat dibandingkan dengan jenis lembaga keuangan non-bank lainnya. Meskipun demikian, bank 
tetap memiliki beberapa kelemahan, seperti sulitnya prosedur dan persyaratan pembiayaan yang menjadikan masyarakat cenderung tidak menyanggupi dan lebih memilih menggunakan jasa keuangan tradisional seperti rentenir dalam memenuhi kebutuhannya akan dana pinjaman. Menurut Sadari dan Hakim (2019) di era digital saat ini, lembaga perbankan tidak boleh hanya melakukan kegiatan operasionalnya secara konvensional atau tradisional saja, dalam arti hanya mengandalkan aktivitas lewat kantor-kantor cabang, yang cenderung bersifat eksklusif. Lembaga perbankan juga harus melakukan sebuah inovasi dalam aktivitas bisnisnya, dan salah satu yang dapat dilakukan yaitu dengan melakukan kerja sama dengan perusahaan fintech.

Munculnya fintech merupakan suatu fenomena tak terhindarkan, dan pertumbuhannya tidak dapat terbendung dewasa ini. Fintech hadir sebagai solusi untuk memberikan kemudahan layanan jasa keuangan bagi masyarakat unbankable yang belum ter-cover oleh perbankan. Namun, ditengah kepopulerannya fintech memiliki beberapa kelemahan seperti kurangnya kepercayaan masyarakat terhadap lembaga fintech itu sendiri karena banyaknya lembaga fintech yang ilegal.

Berdasarkan hal tersebut, pada dasarnya baik perbankan dan lembaga fintech samasama memiliki misi memberi pelayanan terbaik pada nasabah dan oleh karenanya dapat saling melengkapi (Fariana dan Safii, 2018). Namun demikian, adanya kelebihan dan kekurangan dari kedua lembaga tersebut apabila dapat dikolaborasikan dapat menjadi suatu perpaduan yang tepat dalam mendorong tingkat inklusi keuangan Indonesia. Menurut Fariana dan Safii (2018), sinergitas antara perbankan dan lembaga fintech dapat mengurangi blind spots dari masing-masing layanan sebagai hasil dari perpaduan kekuatan masing-masing pihak.

Dari sisi sumber daya manusia, fintech diperkuat dengan talenta-talenta muda yang dinilai sangat inovatif, kreatif, dinamis, dan responsif dalam menjawab kebutuhan nasabah. Begitu juga dengan perbankan, yang memilih model bisnis yang jauh lebih matang serta tenaga professional dengan pengetahuan yang mendalam terkait industri finansial, menguasai customer database yang luas serta regulasi yang proper dari pemerintah sehingga dengan melakukan kerja sama atau kolaborasi tersebut, maka produk-produk layanan jasa keuangan yang ditawarkan oleh perbankan dapat diakses oleh seluruh lapisan masyarakat melalui fiturfitur yang dimiliki oleh fintech (Fariana dan Safii, 2018). Dimana secara tidak langsung, kerja sama tersebut dapat meningkatkan inklusi keuangan Indonesia.

Berdasarkan pemaparan diatas, bentuk kolaborasi yang dinilai cukup efisien ialah adanya suatu kerja sama bagi hasil antara perbankan dengan lembaga fintech. Dalam hal ini, pihak bank dapat berperan sebagai investor yang menginvestasikan sejumlah dananya kepada lembaga fintech dengan tujuan agar dapat menyalurkan sejumlah dana kredit yang belum bisa di jangkau oleh lembaga keuangan tradisional kepada masyarakat yang belum terlayani jasa perbankan. Dimana fintech dapat meng-handle pekerjaan-pekerjaan serupa dengan lembaga perbankan secara lebih efektif dan efisien berbasis teknologi dengan biaya yang ekonomis. Sehingga dengan adanya kolaborasi tersebut seluruh lapisan masyarakat dapat mengakses layanan jasa keuangan, dikarenakan adanya suatu jaringan seperti digital banking yang otomatis me-link kan antara lembaga perbankan dengan fintech sehingga masyarakat khususnya yang terkategori unbankable masih dapat menikmati layanan jasa keuangan yang 
di tawarkan oleh lembaga keuangan tradisional melalui layanan fintech yang sudah bekerja sama dengan lembaga perbankan.

Disamping bank dapat mendayagunakan dana atau modalnya untuk di investasikan kepada lembaga fintech yang muaranya adalah bank, sehingga dapat dirasakan profit yang didapatnya melalui kerja sama tersebut, secara otomatis bank juga telah memberikan peluang untuk menyalurkan dananya kepada masyarakat tanpa persyaratan-persyaratan yang cukup mengikat, melalui lembaga fintech, dimana hal tersebut dapat membantu meningkatkan inklusi keuangan Indonesia, serta mengurangi persentase masyarakat unbankable.

Selain itu, terdapat cara lain yang dapat dilakukan yaitu pihak perbankan menjadi mediator bagi masyarakat unbankable yang hendak memperoleh pinjaman dana agar dapat dialihkan ke lembaga fintech. Sebagai imbalannya, pihak fintech dapat memberikan fee bagi pihak bank yang terkait sesuai dengan kesepakatan kedua belah pihak (perbankan dan lembaga fintech) sehingga dapat terbentuk suatu hubungan simbiosis mutualisme. Dimana dalam hal ini, kolaborasi tersebut dapat menjadikan citra lembaga fintech meningkat di mata calon nasabah karena adanya rekomendasi dari pihak perbankan itu sendiri dan dapat mengurangi resiko menjamurnya lembaga fintech ilegal yang tidak terdaftar pada Otoritas Jasa Keuangan.

\section{PENUTUP}

Berdasarkan pemaparan hasil dan pembahasan yang sudah dijelaskan, maka dapat diberikan kesimpulan sebagai berikut:

1. Kerjasamanya dua lembaga yaitu perbankan dan fintech ini bisa meningkatkan inklusi keuangan di Indonesia, terutama pada masyarakat yang unbankable, selama ini susah mendapatkan bantuan dana dari perbankan karena tidak memenuhi syarat dan ketentuan perbankan dengan adanya kerja sama antara dua lembaga ini masyarakat unbankable bisa mendapatkan dananya dari lembaga fintech guna untuk meningkatkan usaha mereka, yang prosedur peminjamannya lebih mudah dan tidak sebanyak persyaratan dari perbankan.

2. Terdapat 2 Instrumen kolaborasi yang bisa dilakukan oleh lembaga perbankan dan lembaga fintech untuk meningkatkan inklusi keuangan pada masyarakat yang unbankable, yaitu:

a. Bank memberikan dana kepada lembaga fintech sebagai investor untuk membantu pendanaan kepada fintech dalam menyalurkan dana dari perbankan kepada masyarakat;

b. Perbankan menjadi mediator bagi masyarakat unbankable yang hendak memperoleh pinjaman dana agar dapat dialihkan ke lembaga fintech. Sebagai imbalannya, pihak fintech dapat memberikan fee bagi pihak bank yang terkait sesuai dengan kesepakatan kedua belah pihak (perbankan dan lembaga fintech). 


\section{DAFTAR PUSTAKA}

Ansori, M. 2019. Perkembangan dan Dampak Financial Technology (FINTECH) Terhadap di Industri Keuangan Syariah di Jawa Tengah. Jurnal Studi Keislaman 5(1): 32-45.

Basuki, F. H. dan H. Husein. 2018. Analisis SWOT Financial Technology Pada Dunia Perbankan di Kota Ambon (Survei Pada Bank di Kota Ambon). Jurnal Manis 2(1): $60-74$

Chrismastianto, I. A. W. 2017. Analisis SWOT Implementasi Teknologi Finansial Terhadap Kualitas Layanan Perbankan Di Indonesia. Jurnal Ekonomi dan Bisnis 20(1): 133144.

Fariana, A. dan A. Safii. 2018. Sinergi Fintech Dengan Perbankan Syariah Dalam Perspektif Hukum. Jurnal Hukum dan Ekonomi Islam 17(2): 417-430.

Kasmir. 2016. Bank dan Lembaga Keuangan Lainnya. Jakarta: PT Raja Gramedia Pustaka.

Lingga, M. A. 2019. Kelemahan Perbankan Jadi Celah Perkembangan Fintech. Diakses dari https://ekonomi.kompas.com/read/2019/02/27/124407226/kelemahan-perbankanjadi-celah-perkembangan-fintech.

Musdalifah, I., I. A. Rahma, dan B. G. Novalia. 2018. Peran Fintech Dalam Meningkatkan Keuangan Inklusif Pada Umkm Di Indonesia (Pendekatan Keuangan Syariah). Jurnal Masharif al-Syariah: Jurnal Ekonomi dan Perbankan Syariah 3(1).

Nasution, H. 2017. Analisis Financial Inclusion Terhadap Pemberdayaan Masyarakat Miskin di Medan (Studi Kasus Pembiayaan Mikro SS II di Bank SUMUT Syariah). Jurnal Ekonomi dan Bisnis 2(1): 1-20.

Otoritas Jasa Keuangan. 2016. Survei Nasional Literasi dan Inklusi Keuangan 2016. Diakses dari www.ojk.go.id

2017. Fintech Picu Daya Saing. Diakses dari https://sikapiuangmu.ojk.go.id/FrontEnd/CMS/Download/467 dari www.ojk.go.id 2019a. Laporan Profil Industri Perbankan Triwulan I-2019. Diakses 2019b. Penyelenggara Fintech Terdaftar dan Berizin di OJK Per 31 Mei 2019. Diakses dari www.ojk.go.id

Sadari, dan A. Hakim. 2019. Revitalisasi Keuangan Inklusif dalam Sistem Perbankan Syariah di Era Financial Technology. Journal of Islamic Economics, Finance, and Banking 1(1): 1-24.

Sugiyono. 2016. Metode Penelitian Kuantitatif, Kualitatif dan R\&D. Bandung: PT Alfabet.

Wiratno, G. A. 2017. Ada Rp800 Triliun Kebutuhan Kredit Yang Belum Tersentuh Lembaga Keuangan. Diakses dari https://www.wartaekonomi.co.id/read157354/ada-rp800triliun-kebutuhan-kredit-yang-belum-tersentuh-lembaga-keuangan.html. 